\title{
Congress Should Account for the Excess Burden of Taxation
}

\author{
by Christopher J. Conover
}

\section{Executive Summary}

A well-established principle of public finance holds that taxes impose costs on society beyond the amount of revenue government collects. Estimates vary depending on the type of tax, but the "marginal excess burden" of federal taxes most likely ranges from 14 to 52 cents per dollar of tax revenue, averaging about 44 cents for all federal taxes.

The Patient Protection and Affordable Care Act provides a useful illustration. The Congressional Budget Office has projected the 10-year, on-budget cost of the law will be just over $\$ 1$ trillion. This paper estimates PPACA will impose an additional, hidden cost of $\$ 157$ billion to $\$ 494$ billion in the form of reduced economic output. Related provisions (such as the so-called "doc fix") could drive the economic losses to $\$ 550$ billion, or more than half of the bill's official cost estimates. Failing to account for this hidden tax multiplier biases leg- islative decisions toward more costly policies.

For nearly two decades, the U.S. Office of Management and Budget has directed federal agencies to include an average marginal excess burden of 25 cents per dollar when conducting cost-benefit analyses of federal programs.

Congress should direct the Joint Committee on Taxation and Congressional Budget Office to incorporate the excess burden of taxation in their budget analyses, including cost estimates of legislation, baseline budget projections, and budget options. Making such costs visible will encourage policymakers to consider whether the benefits of federal programs equal or exceed the total costs, both visible and hidden. Since the legislation that the $\mathrm{CBO}$ analyzes represents marginal changes from an existing budget and tax baseline, marginal excess burdens would be the most appropriate measure. 


\section{Introduction}

A well-established principle of public finance holds that taxes impose costs on society beyond the amount of revenue government collects. ${ }^{1}$ When the government taxes Peter to pay Paul, Peter views his tax payment as a loss. Those tax payments do not represent a net welfare loss from a societal perspective because Paul experiences an offsetting gain. Taxes do impose costs on society at large, however, in that they encourage Peter not to engage in economic activities that would have benefited him and others. The loss of that economic output is what economists call the "excess burden" or "deadweight loss" of taxation. Virtually all taxes impose deadweight losses.

This paper will first explain the meaning of excess burdens and how they are measured, showing that marginal excess burdens (MEBs) are the most relevant concept for discussing changes in current tax and budget policy. A subsequent section will review the leading estimates of MEBs in the United States, showing how MEBs vary by source of tax revenue and marginal tax rates. The third section will demonstrate why inclusion of such taxrelated welfare costs would be a useful improvement to the standard budget analyses provided by the Joint Committee on Taxation and the Congressional Budget Office when they score legislative proposals, make spending and revenue budget projections, or provide Congress with options for adjusting federal spending and taxes. The fourth section uses the recent health care law to illustrate this approach and how it might inform congressional decisionmaking.

\section{What Are Excess Burdens?}

Economists have confirmed empirically what most laymen understand intuitively: "whatever you tax, you get less of." Taxes on labor, such as income and payroll taxes, tend to reduce the amount people will work. Consumption taxes, like sales, excise, and value-added taxes, reduce the consumption of the taxed items. Capital taxes, such as those on property, dividends, or capital gains, decrease the desirability of investing and reduce the amount of savings available for capital investment. All of these predictable changes in human behavior reduce output (present or future) in some form, thereby reducing the economic welfare of consumers, producers, or both.

Economists measure this loss in terms of reductions in consumer and producer surpluses. In a competitive market, the equilibrium price at which supply matches demand permits many consumers to purchase goods at a cheaper price than they are willing to pay. Imagine you can purchase an apple in the market for 50 cents. If you were willing to pay 50 cents, there would be no net value to you from the transaction: you would give up 50 cents, and receive the equivalent value in the form of an apple. You would be indifferent about keeping your money or buying the apple. But if you were willing to pay 90 cents for the apple, buying an apple for 50 cents increases your net welfare by 40 cents. The amount by which a consumer's willingness to pay exceeds the price is what economists call the "consumer surplus." A parallel calculation applies to producers. In a competitive market, some producers may have been willing to supply apples for only 25 cents, but because the price they get in the market is 50 cents, they enjoy a "producer surplus" of 25 cents.

A sales tax of 50 cents on apples will shift the supply curve up by that amount since producers will still have the same cost per apple as under the old supply curve, but will have to remit 50 cents to the government for each apple sold. This shift in supply will result in consumers demanding a smaller quantity of apples, since the new equilibrium price will be higher (say, 80 cents). Consumers who previously had been willing to pay between 51 and 79 cents for an apple will no longer purchase them. Their loss in welfare-the reduction in their consumer surplus-will be the difference between their willingness to pay and the pretax market price. For each apple no longer pur- 


\section{Figure 1}

The Excess Burden of a Hypothetical Excise Tax on Apples

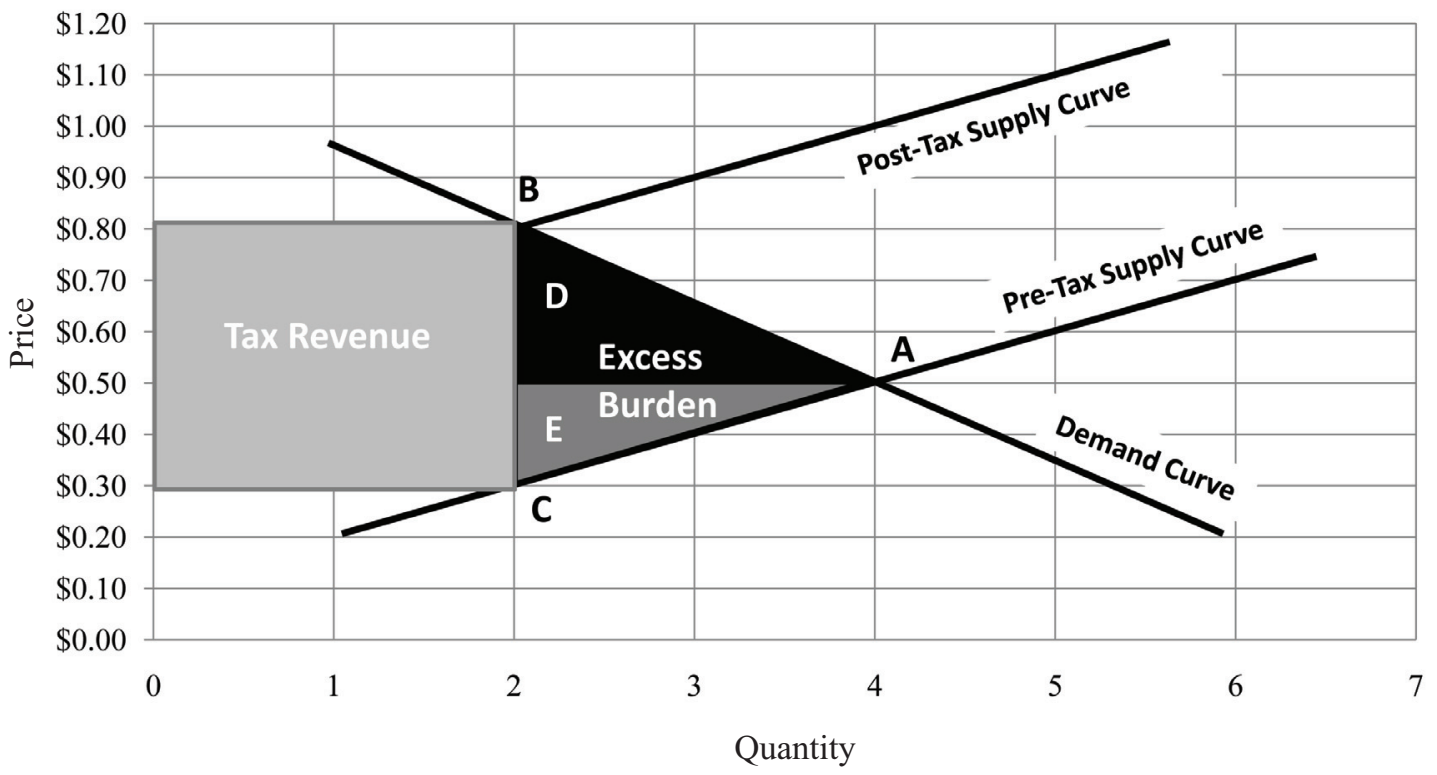

chased, there would be a parallel, though not necessarily equal, reduction in producer surplus that arises due to lower sales of apples.

Figure 1 illustrates these ideas. The pre-tax supply curve intersects the demand curve at point A, where apples sell for 50 cents. An excise tax of 50 cents shifts the supply curve upward to a new equilibrium point $B$ that is 50 cents higher than point $\mathrm{C}$ on the pre-tax supply curve. The shaded rectangle shows the amount of tax revenue collected by the government, while triangles $\mathrm{D}$ and $\mathrm{E}$ respectively show the lost consumer and producer surplus resulting from the tax.

The conventional way of measuring excess burdens is to compare them to the amount of taxes raised. In Figure 1, these losses are approximately one third of total taxes collected. Note that the amount of these welfare losses is smaller than the full market value of whatever production is lost to taxation. This amount is the average excess burden for the hypothetical excise tax.

Since Americans already pay about 18 percent of GDP in federal taxes, ${ }^{2}$ a far more useful concept for assessing the welfare losses associated with increased taxes is the marginal excess burden (MEB). In Figure 1, suppose we increased the 50-cent excise tax to 60 cents. As one moves higher up the demand curve, the ratio of the additional deadweight loss to the additional tax revenue collected will be higher than the previous ratio, which represents the average deadweight loss. ${ }^{3}$ Using the average ratio of deadweight losses to tax revenue will therefore understate the actual welfare loss associated with that tax increase. The MEB is thus the more accurate and appropriate measure. This is especially true if Congress were to include the welfare costs of taxation in its budget analyses since legislative cost estimates, the impact of various budget options, and even baseline projections to the extent they reflect planned changes in tax rates (such as the expiration of the Bush tax cuts in January 2011) represent marginal changes from existing spending and revenue baselines.

\section{How Large Are Excess Burdens?}

If MEBs were trivial amounts, it would hardly be worth the time to include them in
Marginal excess burdens can be substantial. 


\section{The excess burden of a tax increases with the square of the tax rate.}

federal budget estimates. Yet MEBs can be substantial.

One of the earliest studies to measure deadweight losses for income taxes showed that in the United States, such losses were less than 5 percent of income-tax revenue. ${ }^{4}$ In a 1964 paper, Arnold Harberger estimated this using the simple textbook measure of welfare cost (the triangle shown in Figure 1) on grounds that it "yields a good first approximation" of the inefficiency losses arising from such taxes. Harberger developed the following equation to measure the area of the "deadweight loss" triangle created by labor taxes:

$$
D W L=\frac{t^{2} e w L}{2}
$$

where $t=$ the tax rate as a percent of gross wages, $e=$ the wage elasticity of labor supply (taking into account only substitution effects), $w=$ the gross wage rate, and $L=$ the supply of labor. Thus, $w L=$ gross pre-tax wages paid to labor. Harberger assumed the wage elasticity of labor supply (ignoring income effects) to be 0.125 in the United States. Thus, hypothetically, if the average marginal tax rate were to rise from 88.9 percent to 90 percent, the resulting 10-percentage point drop in after-tax wages would cause labor supply to fall by 1.25 percent. Not all of this reduction in labor represents a welfare loss, however, since workers would gain leisure time by not working. Using the formula, the DWL would be $1 / 2(.90)^{2}(.125)$ or 5.1 percent of the amount collected.

As the formula suggests, the excess burden of a tax depends upon two things. The first is the compensated demand or supply elasticity of the good being taxed: the more elastic the demand or supply, the greater the excess burden because taxpayers will substitute away from the good being taxed. The second is the tax rate. As a general rule, the excess burden of a tax increases with the square of the tax rate. The MEB is much higher for a 4 percentage point increase in taxes on top of a marginal tax rate of 40 percent than if the identical increase were added on top of a marginal tax rate of 10 percent. In general, this means that efficiency losses are much lower when a small tax increase is added across a wide tax base than if government raises the identical amount of tax revenue by increasing tax rates at the very top of the income scale.

In the last 15 years, economists have recognized that taxes generate harmful behavioral responses beyond changes in labor supply. Income-tax filers might divert more of their income to nontaxable fringe benefits, avoid taxes by increasing consumption of taxexempt items, or hide income by not declaring it. All of these deviations from what the individual would have done in the absence of taxes increase the excess burden and reduce the amount of tax revenue the government collects. The tax exclusion for employer-provided health benefits, for example, encourages excessive health coverage. A worker taxed at a 50 percent marginal rate has an incentive to purchase health benefits up to the point that the last $\$ 1$ of benefits is worth only 50 cents to the worker, because the worker only has to give up 50 cents of other consumption to obtain $\$ 1$ of health benefits.

The tax exclusion for employer-sponsored health insurance reduces consumer welfare, relative to a world where Congress raises the same amount of revenue with a lower tax rate and no exclusion, by shifting consumption toward health benefits and away from other items that workers value more. The higher the marginal tax rate, the more income shifts to health insurance and the greater the DWL. Hiding income is arguably preferable to the complete elimination of output that generates such income, but it also generates at least some efficiency loss.

If a worker moves from a preferred employment situation to another in which hiding income is easier, that represents a misallocation of labor resources relative to a world where the incentives to hide income are smaller. Also, if the resulting reduction in tax collections leads to higher marginal tax rates on nonhidden income, the average excess burden will rise.

Former Council of Economic Advisers chairman Martin Feldstein argues that a 
more accurate way of assessing excess burdens that encompasses all these changes in behavior should be calculated with the formula

$$
D W L=\frac{\left.\varepsilon t^{2} \text { (Taxable Income }\right)}{2(1-t)}
$$

where $\varepsilon=$ the tax-rate elasticity of reported taxable income, and $t=$ the taxpayer's marginal tax rate. The equation yields dramatically larger estimates of the deadweight loss than Harberger's method.

Table 1 reports different estimates of MEBs based on recent economic literature; details of the estimates are found in the table's footnotes. As shown in Table 1, MEB estimates vary greatly depending on the type of tax, but the most likely estimates range from 14 to 52 cents per dollar of tax revenue, averaging about 44 cents for all federal taxes. At least in part, this difference arises from the large difference in marginal tax rates across different types of tax. The figures shown for custom duties are assumed to be the same as for general sales taxes, which averaged about 7.3 percent across all states in $2009 .^{5}$ In contrast, marginal tax rates for income-tax filers range from 10 to 35 percent. Not surprisingly, there is a larger behavioral response (and accompanying MEB) for the latter compared to the former.

This table also dramatically highlights the difference between marginal and average excess burdens. A relatively recent estimate puts the average excess burden of income taxes at 11.4 to 15 percent of revenue, based on just the highest two income brackets. ${ }^{6}$ Yet Table 1 shows the marginal excess burden at three to four times those levels. To assess the efficiency consequences of changes to existing tax rates accurately, it is critical to focus on marginal excess burdens.

Deficit spending can result in MEBs far larger than the amounts shown in Table 1. One recent analysis estimates that the net present value of current and future-year output losses amount to $\$ 3.40$ for every dollar of federal expenditures financed by borrowing, after accounting for interest payments as well as the tax distortions resulting from the taxes eventually used to pay off debt-financed expenditures. The same method of calculation indicates that tax cuts increase output by $\$ 2.40$ per dollar of revenue foregone-provided, of course, that they are accompanied by spending cuts. ${ }^{7}$ An additional dollar of deficit spending may have the same impact on the national debt as collecting one less dollar of tax revenue. Yet there is a night-andday difference between these two approaches to stimulating the economy in terms of the indirect costs or benefits associated with each in terms of economic output.

\section{Accounting for the Excess Burden of Federal Spending and Taxes}

The excess burden of taxation is a substantial part of the cost of government. Accounting for the excess burden of taxation is essential to honest policymaking.

Accounting for excess burdens is particularly important when policymakers seek to increase taxes on those who already face the highest marginal tax rates. President Obama proposes to raise $\$ 680$ billion in federal revenues over the next 10 years, ${ }^{8}$ largely by letting the top two marginal income tax rates rise from 33 percent $/ 35$ percent to 36 percent $/ 39.6$ percent. ${ }^{9}$ Since the MEB increases by at least the square of the tax rate in the Harberger formulation, or even more than that in the Feldstein formulation, the new tax rates would cost society substantially more than raising $\$ 680$ billion through a smaller acrossthe-board tax increase. Failing to account for this hidden tax multiplier biases legislative decisions toward more costly policies.

The executive branch already incorporates the excess burden of taxation in its cost-benefit analyses. In 1992, the U.S. Office of Management and Budget ordered federal agencies to assign a shadow cost of 25 cents to every dollar of expenditures financed out of tax revenues, a figure based on the available studies. ${ }^{10}$
Letting the top two marginal income tax rates rise would cost society substantially more than raising $\$ 680$ billion through a smaller across-the-board tax increase. 
Table 1

Marginal excess burden of U.S. federal taxes

\begin{tabular}{lcccc}
\hline & $\begin{array}{c}\text { Distribution } \\
\text { of revenues }\end{array}$ & \multicolumn{3}{c}{ Range (percent) } \\
\cline { 3 - 5 } Tax category & (\$ billions) & Minimum & Expected & Maximum \\
\hline All federal taxes $^{2}$ & $2,568.0$ & 18.3 & 44.2 & 111.3 \\
Income taxes $^{3}$ & $1,533.7$ & 23.0 & 50.3 & 161.6 \\
$\quad$ Individual income taxes $^{4}$ & $1,163.5$ & 23.0 & 52.0 & 165.0 \\
$\quad$ Corporate income taxes $^{5}$ & 370.2 & 22.9 & 44.8 & 151.0 \\
Payroll taxes $^{6}$ & 869.6 & 11.2 & 37.6 & 37.6 \\
Excise taxes $^{7}$ & 65.1 & 25.1 & 32.0 & 38.8 \\
Custom duties $^{8}$ & 26.0 & 2.6 & 26.2 & 26.2 \\
Miscellaneous taxes $^{9}$ & 73.6 & 2.6 & 14.4 & 26.2 \\
Other taxes $^{\text {Consumer sales taxes }}{ }^{10}$ & & & & \\
Property taxes $^{11}$ & & 2.6 & 26.2 & 26.2 \\
Individual capital taxes $^{12}$ & & $\mathrm{NR}$ & 17.6 & $\mathrm{NR}$ \\
All capital taxes $^{13}$ & & $\mathrm{NR}$ & 101.7 & $\mathrm{NR}$ \\
Output taxes $^{14}$ & & $\mathrm{NR}$ & 67.5 & $\mathrm{NR}$ \\
\hline
\end{tabular}

Note: $\mathrm{NR}=$ Not reported

${ }^{1}$ Figures are for 2007 (the latest pre-recession year), as reported in Table F-3 of Charles L. Ballard, John B. Shoven, and John Whalley, "General Equilibrium Computations of the Marginal Welfare Costs of Taxes in the United States," American Economic Review 75, no. 1 (March 1985): 128-38.

${ }^{2}$ Figures shown are weighted averages using distribution of revenues as weights.

${ }^{3}$ Ibid.

${ }^{4}$ Minimum is based on a recent review of the literature that recommends using at least 23 percent as the marginal cost of public funds. W. Erin Diewert, Denis A. Lawrence, and Fred Thompson, 1998, "The Marginal Cost of Taxation and Regulation" in Handbook of Public Finance, ed. Fred Thompson and Mark T. Green (New York: Marcel Decker, 1998). Maximum based on Martin Feldstein, "How Big Should Government Be?" National Tax Journal 50 (1996): 197-213. While very high, this study is reportedly "the most comprehensive analysis of the impact of taxation on deadweight losses," using the NBER's TAXSIM econometric model to estimate the impact of the 1993 tax increase. Richard K. Vedder and Lowell E. Gallaway, "Tax Reduction and Economic Welfare," prepared for the U.S. Congress' Joint Economic Committee, April 1999. Unlike most models, Feldstein's analysis captures the full impact of changes in tax rates, including tax avoidance efforts and other behavioral effects not captured in standard models. Expected figure is from D Jorgenson and K-Y Yun general equilibrium model using data from the post-1986 tax changes, as reported in Table 1.2 of Jorgenson and Yun "The Excess Burden of Taxation in the U.S.," in Alberto Heimler and Daniele Muelders, eds., Empirical Approaches to Fiscal Policy Modelling (London: Chapman and Hall, 1993) pp. 9-24.

${ }^{5}$ Minimum is based on marginal excess burden (MEB) calculated by Fullerton and Henderson from general equilibrium model assuming low capital substitution elasticities. Don Fullerton, and Yolanda K. Henderson, "The Marginal Excess Burden of Different Capital Tax Instruments," NBER Working Paper no. 2353, August 1987. Maximum based on upperend MEB results from a 1989 study estimating the range to be 84-51 percent. J. Gravelle and L. Kotlikoff, 1989, "The Incidence and Efficiency Costs of Corporate Taxation When Corporate and Noncorporate Firms Produce the Same Good," Journal of Political Economy 97(4): 749-780. This is similar to the 139-percent estimate obtained in a 1981 study. Roger H. Gordon and Burton G. Malkiel, "Corporation Finance," in How Taxes Affect Economic Behavior, ed, Henry J. Aaron and Joseph A. Pechman (Washington: The Brookings Institution, 1981), pp.131-92. Expected figure is from Jorgenson and Yun, pp. 9-24.

${ }^{6}$ Minimum is based on general equilibrium computations assuming an uncompensated savings elasticity of 0.4 and uncompensated labor supply elasticity of 0 , as reported in Ballard, Shoven, and Whalley. Maximum figure is for all labor 
income from Jorgenson and Yun general equilibrium model using data from the post-1986 tax changes, as reported in Table 1.2. D. Jorgenson and K-Y Yun, pp. 9-24. This figure also is used as the expected value since it is based on post1986 tax structure, whereas Ballard et al. results are from an earlier period. These figures will overstate MEBs if workers view each dollar in Social Security taxes as purchasing deferred labor compensation in the form of a pension with a present value of a dollar; in such a case the effective marginal tax rate would be zero. Edgar K. Browning, "On the Marginal Welfare Cost of Taxation," American Economic Review 77, no. 1 (March 1987): 11-23; and "United States International Trade Commission. Harmonized Tariff Schedule of the United States," http:/www.usitc.gov/tata/hts/ bychapter/index.htm.

${ }^{7}$ Figures shown are for consumer sales taxes, which include federal excise taxes on alcohol, tobacco, and gasoline and the average retail sales tax rate across states. Because the excise tax rate is much higher for the first three commodities compared to the average state sales tax rate, this will understate the excess burden, but only blended figures were reported. Minimum is based on general equilibrium computations assuming an uncompensated savings elasticity of 0.4 and uncompensated labor supply elasticity of 0 . Maximum assumes uncompensated savings elasticity of 0 and uncompensated labor supply elasticity of .15. Expected value is the average of these two estimates and two intermediate estimates (.121 and .230) reported in Ballard, Shoven, and Whalley, pp. 28-38.

${ }^{8}$ Figures assumed to be the same as for state general sales taxes. Import duties are highly variable. United States International Trade Commission. Yet they appear to average more than the 6.7 percent marginal tax rate reported for consumer purchase taxes in Table 2 of Ballard et al., pp. 128-38. Thus, the MEBs shown likely understate the actual values.

${ }^{9}$ Includes estate and gift taxes and all other federal taxes not listed separately. To be conservative, minimum and maximum figures are based on the minimum value from among each source of federal tax revenue listed. The expected value is an average of the minimum and maximum.

${ }^{10}$ Figures shown are for commodities other than alcohol, tobacco and gasoline (i.e., state general sales taxes). Minimum is based on general equilibrium computations assuming an uncompensated savings elasticity of 0.4 and uncompensated labor supply elasticity of 0 , as reported in Ballard, Shoven, and Whalley, pp. 128-138. Maximum figure is for all labor income from Jorgenson and Yun. This figure is also used as the expected value since it is based on post-1986 tax structure, whereas Ballard et al. results are from an earlier period.

${ }^{11}$ Expected figure is from Jorgenson and Yun. No other estimates of MEBs for this form of tax could be located.

${ }^{12}$ Ibid.

${ }^{13}$ Ibid.

${ }^{14}$ Minimum is based on general equilibrium computations assuming an uncompensated savings elasticity of 0 and uncompensated labor supply elasticity of 0 . Maximum assumes uncompensated savings elasticity of 0.4 and uncompensated labor supply elasticity of .15. Expected value is the average of these two estimates and two intermediate estimates (.163 and .248) reported in Ballard, Shoven, and Whalley, pp. 128-38.

The excess burden of taxation already plays a minor role in policy debates. The debate over national health insurance during the Carter administration highlighted the importance of accounting for tax-related efficiency losses. ${ }^{11}$ Others voiced a similar concern as health reform re-emerged as an issue in the early 1990s. ${ }^{12}$ An analysis that compared a fully government-financed universal coverage system to a system that achieved universal coverage through an individual mandate and tax credits found that the tax-related efficiency losses were roughly twice as large under the first option compared to the second. ${ }^{13}$ Excess burdens will not receive the attention they deserve, however, until Congress includes them in its official cost estimates.

\section{The Patient Protection and Affordable Care Act of 2010}

The recently enacted Patient Protection and Affordable Care Act of 2010 provides an important illustration of the magnitude of excess burdens and how failing to account for them can distort policy decisions. The CBO score for the final version of PPACA (including the reconciliation proposal) projected that the law would reduce the deficit by $\$ 143$ billion during its first 10 years. ${ }^{14}$ During that period, revenues would increase by $\$ 420$ billion (excluding $\$ 32$ billion in revenues from the excise tax on high-cost insurance plans). ${ }^{15}$ While subsequent $\mathrm{CBO}$ estimates showed the net reduction in the deficit to be much smaller
Excess burdens will not receive the attention they deserve until Congress includes them in its official cost estimates. 


The total excess
burden associated
with PPACA
could amount to
$\$ 550$ billion, or
more than half of
the bill's official
cost estimate.

once other costs were taken into account, let us assume this was the most accurate information available to members of Congress at the time of the final vote. If we categorize the revenue provisions by type of income and apply the MEB percentages shown in Table 1, the estimated welfare losses associated with PPACA amount to $\$ 157$ billion, though they may be as high as $\$ 229$ billion. Thus, for every dollar of purported deficit reduction, there will be a corresponding reduction in economic output of between $\$ 1.10$ and $\$ 1.60$. Because Congress does not include the excess burden of taxation in its cost estimates, many members of Congress and many of their constituents were not aware of these additional costs. Had they been aware, PPACA may have struck even more members of Congress as not being a good deal, particularly in a weak economy.

The final CBO score of the health bill also assumed that the federal government would trim \$455 billion in spending on Medicare, Medicaid, and the State Children's Health Insurance Program. Given the difficulties Congress has in keeping past pledges to trim Medicare, independent observers have cast doubt on whether such savings will materialize. ${ }^{16}$ If Congress eventually rescinds those spending reductions and raises income taxes to fill the gap, the welfare losses would rise by an additional $\$ 237$ billion (and possibly as much as $\$ 750$ billion).

The so-called "doc fix"-an increase in Medicare's physician price controls that would avert a 21-percent cut in those prices-was removed from an earlier version of the legislation, and some argue it should have been included in the cost of PPACA. A permanent "doc fix" would cost the federal treasury roughly $\$ 300$ billion over 10 years, but increase the welfare losses by another $\$ 156$ billion (and possibly as much as $\$ 495$ billion).

If all of these costs materialize-which some might argue is a "most-likely-case" scenario-the total excess burden associated with PPACA could amount to $\$ 550$ billion, or more than half of the bill's official cost estimate and \$3.85 per dollar of supposed deficit reduction. Using the upper-bound estimates, the total excess burden would amount to $\$ 1.5$ trillion, or $\$ 10.31$ per dollar of deficit reduction. Again, were Congress to finance any of these expenditures through borrowing rather than by raising current taxes, the total excess burden associated with PPACA would be even larger.

\section{The Next Health Care Debate}

Failure to consider MEBs may bias the views of legislators in favor of approaches to expanding coverage that may be considerably less cost-effective. Some of the most influential players in the recent health care debatemost notably President Obama-would have preferred a single-payer health plan to PPACA. The American public may one day face a choice between a single-payer health care system and a market-oriented system that uses income-related tax credits to expand coverage.

Even if one accepts the exaggerated administrative cost advantage accorded to Medicare by single-payer advocates-allegedly 9 percentage points according to the most enthusiastic academic proponent of the public health option ${ }^{17}$-such savings would be swamped were MEBs taken into account. If 100 percent of health spending were income-tax-financed under a Canadian-style, single-payer system, but only half the costs of a tax credit system were tax-financed, the total social cost of the single-payer system would be 24 percent higher-even if we assume that the tax-credit system costs 9 percent more due to higher administrative costs. The tax credit system would still have a net cost advantage of 17 percent if the two were financed through payroll taxes, and 12 percent if they were funded through a value-added tax. Leaving aside all other advantages of a market-oriented system, introducing an explicit consideration of MEBs dramatically alters the assessment of which approach is most cost-effective.

Whether the excess burden is only 26 cents on the dollar or $\$ 1.65$ on the dollar, accounting for MEBs confirms the basic intuition that providing Warren Buffett or Bill Gates with tax-financed health benefits is an extraordinarily inefficient use of tax dol- 
lars. It may well be that a single-payer system provides some of the "solidarity benefits" championed by its proponents. But voters have a right to know the full cost of that solidarity before making their choice.

\section{Conclusion}

Congress should not commit scarce tax resources to any initiatives until lawmakers have a full accounting of the costs and benefits. Congress should direct the Joint Committee on Taxation and the Congressional Budget Office to include the excess burden of taxation in their revenue and cost estimates, baseline projections, and budget options.

With a struggling economy and looming unfunded liabilities of \$107 trillion in Social Security and Medicare, ${ }^{18}$ Americans cannot afford not to consider the full cost of government. It is irresponsible for members of Congress and the president to spend taxpayers' earnings without understanding the full burden they are imposing on those taxpayers.

President Obama and House Speaker Nancy Pelosi have both asserted their commitment to more transparency in government. They, along with Democrats and Republicans in both chambers of Congress, should insist on this small change to CBO's scorekeeping that will help federal officials make more honest and responsible policy decisions.

\section{Notes}

1. See, for example, Jonathan Gruber, "Tax Inefficiencies and Their Implications for Optimal Taxation," in Public Finance and Public Policy (New York: Worth Publishers, 2005), pp. 547-58.

2. U.S. Congressional Budget Office, "Budget and Economic Outlook: Historical Budget Data,"January 2010, http://www.cbo.gov/ftpdocs/108xx/ doc10871/historicaltables.pdf.

3. The area of the shaded "tax revenue" rectangle may increase or decrease, depending on the price elasticities of supply and demand. In contrast, the area(s) of the "excess burden" triangle(s) would increase unambiguously.
4. Arnold C. Harberger, "Taxation, Resource Allocation, and Welfare," in The Role of Direct and Indirect Taxes in the Federal Revenue System, ed. John F. Due (Princeton, NJ: Princeton University Press, 1964), pp. 25-70.

5. Across the 47 states with sales taxes, the population-weighted average combined state and local sales tax in 2009 was 7.3 percent (figure calculated by author using U.S. Census data on resident population by state, available in the U.S. Statistical Abstract 2010 and population-weighted combined tax rates reported for each state in Tax Foundation, Inc., "Combined State \& Local Sales Tax Rates as of September 29, 2009," http://www.tax foundation.org/files/state\&local_combined_sale stax_rate-sept2009-20100325.xls).

6. Robert Carroll, The Excess Burden of Taxes and the Economic Cost of High Tax Rates, Washington, Tax Foundation, Special Report no. 170, August 2009, http://www.taxfoundation.org/files/sr170.pdf.

7. Harald Uhlig, "Understanding the Impact of Fiscal Policy: Some Fiscal Calculus," American Economic Review: Papers e Proceedings 100 (May 2010): 30-34. Uhlig estimates the net present value of output losses over a 40-year horizon.

8. Adam Looney, "The Debate over Expiring Tax Cuts: What about the Deficit?” Tax Policy Center, August 12, 2010, p. 1, http://www.taxpolicycen ter.org/UploadedPDF/1001438-tax-cuts-debate. pdf.

9. See U.S. Joint Committee on Taxation, "Description of Revenue Provisions Contained in the President's Fiscal Year 2011 Budget Proposal," August 16, 2010, p. 23, http://jct.gov/publications. html? func $=$ download \&id $=3703 \& \mathrm{chk}=0 \mathrm{ffc} 22 \mathrm{ebe} 9 \mathrm{e}$ 51a452308eb72d0b87729\&no_html=1.

10. Office of Management and Budget, Circular A94. Guidelines and Discount Rates for Benefit-Cost Analysis of Federal Programs, October 29, 1992, http: //www.whitehouse.gov/omb/circulars_default/. This new guidance applied only to public investments that do not decrease federal spending, since presumably any such cost reduction would be accompanied by a decrease in deadweight losses as well. Inclusion of excess burdens also is not required for cost-effectiveness or lease-purchase analyses. The OMB permitted agencies to use a higher or lower figure in some circumstances. For example, tobacco taxes arguably are Pigouvian levies that assign a price to the externalities associated with smoking (e.g., second-hand smoke), in which case OMB would allow the monetary value of such benefits to be deducted from the estimated MEB. 
11. Edgar K. Browning and William R. Johnson, "Taxation and the Cost of National Health Insurance," in Mark V. Pauly, ed., National Health Insurance: What Now, What Later, What Never? (Washington: American Enterprise Institute, 1980).

12. Joseph Newhouse, "Medical Care Costs: How Much Welfare Loss?” Journal of Economic Perspectives 6 (Summer 1992): 3-21; Patricia M. Danzon, "Hidden Overhead Costs: Is Canada's System Less Expensive?" Health Affairs 11 (Spring 1992): 21-43.

13. Charles L. Ballard, and John H. Goddeeris. "Financing Universal Health Care in the United States: A General Equilibrium Analysis of Efficiency and Distributional Effects." Unpublished manuscript, revised. Lawrence H. Summers, "Some Simple Economics of Mandated Benefits," American Economic Review 79, no. 2 (May 1989): 177-83

14. Congressional Budget Office, H.R. 4872, Reconciliation Act of 2010 (Final Health Care Legislation). Cost estimate for the amendment in the nature of a substitute for H.R. 4872, incorporating a proposed manager's amendment made public on March 20, 2010, http://www.cbo.gov/ doc.cfm? index $=11379$ \& type $=1$.

15. The revenues from the so-called "Cadillac tax" on health plans are excluded from the calculations for simplicity. We do not have a good MEB estimate to apply to such an excise tax; moreover, to the degree that such a levy is viewed as a Pigouvian tax aimed at reducing the inefficiencies related to excess health coverage, a case could be made for using a relatively low MEB value. Thus, excluding this relatively small component of revenue increases will result in a relatively small underestimate of the total impact of PPACA on economic output.
16. See Richard S. Foster, "Estimated Financial Effects of the 'Patient Protection and Affordable Care Act,' as Amended," memorandum, April 22, 2010, https://www.cms.gov/ActuarialStudies/Down loads/PPACA_2010-04-22.pdf ("It is important to note that the estimated savings shown in this memorandum for one category of Medicare provisions may be unrealistic"); U.S. Congressional Budget Office, letter to the Honorable Harry Reid, December 19, 2009, http://cbo.gov/ftpdocs/108xx /doc10868/12-19-Reid_Letter_Managers_Correc tion_Noted.pdf ("It is unclear whether such a reduction in the growth rate [of Medicare outlays] could be achieved"); and International Monetary Fund, Fiscal Monitor: Navigating the Fiscal Challenges Ahead, May 14, 2010, http://www.imf.org/external/ pubs/ft/fm/2010/fm1001.pdf ("The substantial decrease in Medicare payment rates to health care providers may prove difficult to implement").

17. Jacob S. Hacker, The Case for Public Plan Choice in National Health Reform (Berkeley: University of California, Berkeley School of Law, December 2008).

18. The infinite time horizon estimates of unfunded liabilities for Medicare (after deducting current trust fund balances) total $\$ 88.9$ trillion and are reported in U.S. Centers for Medicare \& Medicaid Services, The 2009 Annual Report of the Boards of Trustees of the Federal Hospital Insurance and Federal Supplementary Medical Insurance Trust Funds, May 12, 2009, Table III.B10, Table III.C16, and Table III.C23, http://www.cms.gov/ReportsTrust Funds/downloads/tr2009.pdf. The parallel figure for Social Security is $\$ 15.1$ trillion as reported in U.S. Social Security Administration, The 2009 Annual Report of The Board Of Trustees of The Federal Old-Age And Survivors Insurance and Federal Disability Insurance Trust Funds, May 12, 2009, Table IV.B7, http://www.ssa.gov/OACT/TR/2009/tr09.pdf. 


\section{RELEVANT STUDIES IN THE POLICY ANALYSIS SERIES}

527. Health Care Regulation: A $\$ 169$ Billion Hidden Tax by Christopher J. Conover (October 4, 2004)

657. The Massachusetts Health Plan: Much Pain, Little Gain by Aaron Yelowitz and Michael F. Cannon (January 19, 2010)

656. Obama's Prescription for Low-Wage Workers: High Implicit Taxes, Higher Premiums by Michael F. Cannon (January 13, 2010)

650. Yes, Mr. President: A Free Market Can Fix Health Care by Michael F. Cannon (October 21, 2009)

632. A Better Way to Generate and Use Comparative-Effectiveness Research by Michael F. Cannon (February 6, 2009)

574. Budgeting in Neverland: Irrational Policymaking in the U.S. Congress and What Can Be Done about It by James L. Payne (July 26, 2006)

536. Options for Tax Reform by Chris Edwards (February 24, 2005)

463. Reforming the Federal Tax Policy Process by David R. Burton (December $17,2002)$

302. The Hidden Burden of Taxation: How the Government Reduces TakeHome Pay by Dean Stansel (April 15, 1998)

\section{RECENT STUDIES IN THE POLICY ANALYSIS SERIES}

668. Fiscal Policy Report Card on America's Governors: 2010 by Chris Edwards (September 30, 2010)

667. Budgetary Savings from Military Restraint by Benjamin H. Friedman and Christopher Preble (September 23, 2010)

666. Reforming Indigent Defense: How Free Market Principles Can Help to Fix a Broken System by Stephen J. Schulhofer and David D. Friedman (September 1, 2010)

665. The Inefficiency of Clearing Mandates by Craig Pirrong (July 21, 2010)

664. The DISCLOSE Act, Deliberation, and the First Amendment by John Samples (June 28, 2010)

663. Defining Success: The Case against Rail Transit by Randal O'Toole (March 24, 2010) 
662. They Spend WHAT? The Real Cost of Public Schools by Adam Schaeffer (March 10, 2010)

661. Behind the Curtain: Assessing the Case for National Curriculum Standards by Neal McCluskey (February 17, 2010)

660. Lawless Policy: TARP as Congressional Failure by John Samples (February 4, 2010)

659. Globalization: Curse or Cure? Policies to Harness Global Economic Integration to Solve Our Economic Challenge by Jagadeesh Gokhale (February 1, 2010)

658. The Libertarian Vote in the Age of Obama by David Kirby and David Boaz (January 21, 2010)

657. The Massachusetts Health Plan: Much Pain, Little Gain by Aaron Yelowitz and Michael F. Cannon (January 20, 2010)

656. Obama's Prescription for Low-Wage Workers: High Implicit Taxes, Higher Premiums by Michael F. Cannon (January 13, 2010)

655. Three Decades of Politics and Failed Policies at HUD by Tad DeHaven (November 23, 2009)

654. Bending the Productivity Curve: Why America Leads the World in Medical Innovation by Glen Whitman and Raymond Raad (November 18, 2009)

653. The Myth of the Compact City: Why Compact Development Is Not the Way to Reduce Carbon Dioxide Emissions by Randal O’Toole (November 18, 2009)

652. Attack of the Utility Monsters: The New Threats to Free Speech by Jason Kuznicki (November 16, 2009)

651. Fairness 2.0: Media Content Regulation in the 21st Century by Robert Corn-Revere (November 10, 2009)

650. Yes, Mr President: A Free Market Can Fix Health Care by Michael F. Cannon (October 21, 2009)

649. Somalia, Redux: A More Hands-Off Approach by David Axe (October 12, 2009) 